\title{
When does schizophrenia really begin? - A case report confirming the neurodevelopmental theory of schizophrenia
}

\author{
Kiedy tak naprawdę zaczyna się schizofrenia?- opis przypadku potwierdzający teorię \\ neurorozwojową schizofrenii \\ Julita Szarpak ${ }^{1}$ ADEF, https://orcid.org/0000-0002-5091-0235, \\ Karol Ciejka ${ }^{1}$ DF, https://orcid.org/0000-0003-0799-2607, \\ Weronika Perczyńska1 EF, https://orcid.org/0000-0002-2487-2650, \\ Michał Flis ${ }^{2}$ BE, https://orcid.org/0000-0002-4831-9091, \\ Paulina Wróbel-Knybel² ABEF, https://orcid.org/0000-0002-4741-5911
}

${ }^{1}$ Student Research Group at the I Department of Psychiatry, Psychotherapy and Early Intervention, Medical University of Lublin, Poland

${ }^{2}$ I Department of Psychiatry, Psychotherapy and Early Intervention, Medical University of Lublin, Poland

\begin{abstract}
Introduction: According to the neurodevelopmental theory, schizophrenia is a cognitive-behavioral manifestation of the nonphysiological development of the CNS, which was caused by the interaction of genetic and environmental factors during its formation.

Aim, material and methodology: The aim of this article is to present a clinical case in which exposure to numerous adverse environmental factors in the pre and postnatal period could cause the development of schizophrenia in adulthood. The analysis of the clinical case and the medical records of a patient diagnosed with paranoid schizophrenia, suffering from numerous perinatal complications, was performed.

Case report: A woman, 23 years old, unmarried, studying at post-secondary school - archivistics. Currently, psychiatrically hospitalized for the second time. A patient from the first, twin, fraternal pregnancy. The delivery took place by caesarean section, complicated. In the APGAR scale, she scored 4 points in the 1st minute, and 6 points in the 3rd minute. By day 30, the patient had experienced preterm retinopathy, viral infection, salmonella, jaundice and anemia. In the second month of her life, she was treated with surgery due to intestinal obstruction. Psychomotor development was disturbed. At 9 years of age, there was a retinal detachment. Until the end of junior high school, she was educated in a special school for the visually impaired.

Conclusions: The neurodevelopmental theory assumes that the increased risk of developing schizophrenia is associated with unfavorable factors in the developmental period. Identifying the causes underlying the development of the disease is a key step towards prevention, more efficient diagnosis, and improvement of the effectiveness of treatment of patients suffering from this disease.
\end{abstract}

Keywords: synaptic pruning, neurodevelopment, schizophrenia, genetic

\section{Streszczenie}

Wstęp: Według teorii neurorozwojowej schizofrenia jest poznawczo-behawioralną manifestacją niefizjologicznego rozwoju OUN, który został spowodowany współdziałaniem czynników genetycznych i środowiskowych jeszcze podczas jego kształtowania.

Cel pracy, materiał i metodyka: Celem niniejszego artykułu jest przedstawienie przypadku klinicznego, w którym ekspozycja na liczne niekorzystne czynniki środowiskowe w okresie pre i postnatalnym mogła być przyczyną rozwoju schizofrenii w życiu dorosłym. Dokonano analizy przypadku klinicznego i dokumentacji medycznej pacjentki z rozpoznaniem schizofrenii paranoidalnej, u której wystąpiły liczne powikłania okołoporodowe. 
Opis przypadku: Kobieta, 23-letnia, panna, w trakcie nauki w szkole policealnej- archiwistyka. Aktualnie drugi raz hospitalizowana psychiatrycznie. Pacjentka z ciąży pierwszej, bliźniaczej dwujajowej. Poród odbył się poprzez cięcie cesarskie, powikłany. W skali APGAR uzyskała 4 punkty w 1. minucie, i 6 punktów w 3. minucie. Do 30 dnia życia pacjentka przebyła retinopatię wcześniaczą, zakażenie wirusowe, salmonellę, żółtaczkę i niedokrwistość. W drugim miesiącu życia leczona była operacyjne z powodu niedrożności jelit. Rozwój psychoruchowy był zaburzony. W 9 roku życia wystąpiło odwarstwienie siatkówki. Do końca szkoły gimnazjalnej kształcona w szkole specjalnej dla osób niedowidzących.

Wnioski: Teoria neurorozwojowa zakłada, że zwiększone ryzyko rozwoju schizofrenii wiąże się z zadziałaniem niekorzystnych czynników w okresie rozwojowym. Identyfikacja przyczyn leżących u podłoża rozwoju choroby jest kluczowym krokiem w kierunku prewencji, sprawniejszej diagnostyki oraz poprawienia skuteczności leczenia pacjentów cierpiących na tę chorobę.

Słowa kluczowe: przycinanie synaptyczne, neurorozwojowy, schizofrenia, genetyczny

\section{Introduction}

Schizophrenia is a disease of a complex nature and heterogeneous symptoms in behavioral and cognitive aspects [1]. Its course varies individually and may be manifested in a single episode, from relapses interrupted by asymptomatic periods, to a form characterized by the constant occurrence of symptoms [2]. According to the Global Burden of Disease report from 2017, the disease affects over 20 million people worldwide [3]. It is estimated that about $2 / 3$ of new diagnoses of schizophrenia are made before the age of 45 [2]. This disease is responsible for the deterioration of the quality of life and reduced participation in the professional life and social environment [2]. Compared to 2007, the Years Lived With Disability (YLD) index, including schizophrenia, calculated a decade later, increased by approximately $17.2 \%$ [3]. An important fact concerning people suffering from this disease is that their life expectancy may even be 10 to 25 years shorter compared to the general population $[4,5]$.

At the moment, it is not possible to unequivocally identify the causes of schizophrenia, and the detailed pathogenesis of this disease is the subject of many ongoing studies. The proposed concepts are based on the interaction of many factors, among which the most important role seems to be the genetic and environmental aspects as well as the abnormal development of the central nervous system (CNS) at various stages of its formation. Schizophrenia is characterized by high heritability, it is estimated that the risk of developing the disease is up to 17 times higher in first-degree relatives, and up to 4050 times higher in monozygotic twins compared to the general population [6]. Despite numerous studies on the human genome, it was only possible to establish that some genes may predispose to the development of schizophrenia in the future, but only their altered expression is not responsible for the appearance of symptoms $[7,8,9]$.

Exposure to environmental factors correlating with abnormal neurodevelopment can occur in the prenatal, childhood, and adolescence periods. Among the stimuli acting during fetal life, which may predispose to the occurrence of anomalies, there are Toxoplasma gondii infection [10], malnutrition [11], iron [12], and vitamin D deficiency [13] in pregnant women. Perinatal complications, such as pre-eclampsia or preterm birth, may have a similar effect [14]. During childhood and adolescence, traumas and low socioeconomic status also gain significant importance for the development of the nervous system [15].

The neurodevelopmental theory of schizophrenia is based on the assumption that the symptomatic form is the final result of the non-physiological development of the CNS, which was caused by the interaction of genetic and environmental factors during its formation. The concept of the abnormal structure of the CNS as the cause of schizophrenia was first proposed about 30 years ago by I. Feinberg [16], T. Crow [17], D. Weinberger [18], R. Murray, and S. Lewis [19]. From that moment on, this theory was supplemented with the element of the so-called "second hit". J. Davis et al. in their work postulate that this model may be characterized by an oversimplification of the pathogenesis of schizophrenia, and that a chance to better reflect the interaction of genetic, environmental, and social factors is offered by the "multiple hits" hypothesis at key moments in the development of the CNS [15].

The theory of the neurodevelopmental basis of schizophrenia is reflected in imaging studies of the CNS. Using one of the sequences of magnetic resonance imaging (MRI), diffusion tensor imaging (DTI), it has been shown that the amount of white matter in people with schizophrenia is reduced in as many as 15 regions of the brain, mainly in the right upper temporal lobe and in the corpus callosum already in the initial period of the disease [20]. Deficits also affect the gray matter, in particular the frontal cortex, the insula, and the superior temporal gyrus [21]. The changes present in the CNS also include a reduced density of dendritic spines covering synapses [22] and a reduced amount of synaptic proteins [23].

The aim of this article is to present a clinical case in which exposure to numerous adverse environmental 
factors in the pre and postnatal period could cause the development of schizophrenia in adulthood.

\section{Method}

Analysis of a clinical case and medical documentation of a patient diagnosed with paranoid schizophrenia, with multiple perinatal complications. The case analysis was based on bibliographic data (number of items - 36), published in the years 1982-2021, and obtained from databases; PubMed, Google Scholar.

\section{Case report}

Patient at the age of 23, unmarried, childless. After receiving secondary education, she entered a postsecondary school, which she currently attends. The patient's parents are divorced, she lives with her mother, but she has occasional contact with her father. The patient has a healthy, dizygotic twin sister. In the interview, she denies the abuse of alcohol and psychoactive substances. The family history of mental disorders and genetic diseases is positive on the part of the distant family of the patient's father, the exact diagnosis is unknown.

Patient from a first twin pregnancy, first delivery. The delivery was by caesarean section in the 29th week of pregnancy due to maternal pyelonephritis. Bodyweight at birth was $1010 \mathrm{~g}$ (standard weight is about 2800-3800 g). In the Apgar Score, she obtained 4 points in the first minute and 6 points in the third minute, both scores indicate a moderately abnormal condition of the newborn baby. In the perinatal period, there were complications in the form of breech presentation, necrotizing enterocolitis, intestinal obstruction, and bilateral pneumonia. In the neonatal period, the patient experienced retinopathy of prematurity, salmonella, viral infection, jaundice, anemia. In the second month of life, an operation was performed due to intestinal obstruction. From birth, the patient was fed artificially with milk mixtures.

The milestones were reached on time with the exception of the speech, which appeared around the age of 4 , and the walking skills which she developed at the age of 2. At the age of 5, psychomotor development was impaired, and developmental delay was estimated to be retarded by one year compared to the peer group. At the age of 9 , she developed a retinal detachment, therefore she was treated surgically. Due to the high vision defect and mental development at a lower than average level, the patient was educated in a special school for visually impaired people in junior high and primary schools. In secondary school and high school, she was exempted from physical education due to severe abdominal pain, fever, occurring after physical activity, caused by postoperative adhesions in the abdominal cavity.

\section{State on admission and medical history}

The first disorders began in April 2018 in the form of persecutory delusions and delusions of reference as well as auditory hallucinations (commenting and threatening voices) and olfactory hallucinations. Due to the significant intensification of productive symptoms, on 07/06/2018 - 12/06/2018, the patient was hospitalized at the Neuropsychiatric Hospital in Lublin with the diagnosis: Acute and transient psychotic disorders, unspecified (F23.9). On June 12, 2018, she was admitted to the Department of Child and Adolescent Psychiatry of the local Department of Psychiatry, Psychotherapy, and Early Intervention in Lublin to continue treatment. On admission, the patient was properly oriented auto- and allopsychically. She demonstrated logical verbal contact and the mood and drive were balanced. She did not spontaneously express delusional content, denied the occurrence of hallucinations and suicidal thoughts. In the MINI scale, she obtained 0 points, which indicated a low risk of suicide.

On the first day after admission (i.e. August 13, 2018), fasting blood was taken, and the results of laboratory tests showed the following abnormalities: glucose - 99.4; (standard: 70-99 mg / dl), total protein - 5.73; (standard: 6.40-8.30 g / dl), total cholesterol - 108.6; (standard: 115-190 mg / dL), FT4 free thyroxine- 20.32; (standard: 9.0-20.0 pmol / l), \% neutrocytes - 73.3; (standard: 45.070.0\%), \% lymphocytes - 17.5; (standard: 20.0-45.0), \% eosinocytes - 0.20; (standard: 1.0-5.0). The patient's BMI was 19.63, which parallel to normal body weight.

\section{The course of hospitalization and applied treatment:}

Initially, the patient was affective pale, with significantly reduced psychomotor drive, aspontanic, passive and apathetic. She expressed delusional content of a persecutory nature and delusion of reference. She reported the presence of complex hallucinations (commenting voices) and simple hallucinations (knocking). Occasionally, she complained about the presence of olfactory hallucinations (unpleasant smells, the smell of "corpses"). She answered the questions asked in single words, the statements were very impoverished, she spoke in a low voice.

On the day of admission, the patient was given a perazine, (tab. p. o.), in a dose of $25 \mathrm{mg}$ and pridinol, (tab. p. o.), at a dose of $5 \mathrm{mg}$ (the patient's current treatment) and continued treatment with olanzapine, (tab. p.o.), gradually increasing the dose over the next few days to 20 $\mathrm{mg} /$ day. Due to the persistence of productive symptoms, as well as significant slowing down of movement and apathy in the patient, on the 22nd day of hospitalization, aripiprazole tablets (p. o.) were included in the treatment, after reaching the maximum dose of $30 \mathrm{mg}$. Despite the 
implemented pharmacotherapy, the patient's condition did not improve satisfactorily. On day 51 of hospitalization, risperidone tablets (p. o.) were started on (the maximum dose used was $3 \mathrm{mg}$ ) and on day 58, sertraline (maximum dose $100 \mathrm{mg}$ ). The patient was qualified for electrical procedures, but due to the left ovarian cyst, it was necessary to withdraw from this form of therapy. A decision was made to gradually discontinue olanzapine, and after excluding any contraindications, clozapine was introduced, and the dose was gradually increased to 175 mg. During hospitalization, the patient benefited from supportive psychotherapy, psychoeducation, occupational and music therapy, art therapy, and culinary training.

During the hospitalization, a number of laboratory and imaging tests were performed, as well as neurological, internal medicine, gynecological and ophthalmological consultations. One week after taking olanzapine, the patient had an electroencephalographic examination which showed abnormalities. Generalized lesions were visible, with unstable, bilateral, more clearly marked on the right side, predominance in the fronto-temporal regions, in the form of theta waves, occasionally highervoltage discharges of irregular theta-delta waves and sharp ones. Basic activity was irregular, with free theta waves scattered over the frontal area of the brain.

The patient was consulted neurologically because of an abnormal EEG test result and complaints about unpleasant odors (the smell of "corpse"). The consulting neurologist recommended an MRI of the head, which was performed on July 2, 2018, in order to rule out the suspicion of temporal disorders. The test result was normal, with no abnormalities. Due to the reported abdominal pain, the patient was consulted gynecologically, ultrasound showed an endometrial cyst of the left ovary, and the patient was referred for surgery.

In the study conducted with the use of the WAIS-R PL Intelligence Scale, general mental performance was determined on the verge of normal and impairment, in the Full Scale II = 78. There was no statistically significant difference between verbal abilities (on the Verbal Scale II $=80$ ) and non-verbal abilities (on the Wordless Scale $\mathrm{II}=77$ ). During the performance of the tasks, the patient showed commitment. The skills that the patient performed favorably include: short-term auditory memory, direct recall, predicting relationships between elements, and their integration. The ability to interpret and organize material using eyesight and resistance to distractors were below average.

Another electroencephalographic examination during risperidone, aripiprazole, and sertraline therapy was performed on August 14, 2018. There was an improvement in the record compared to the previous study, but there were also irregularities. Generalized changes, also more visible in the right frontotemporal region, were poorly emphasized, activated by hyperventilation, single high-voltage delta-theta discharges.

The patient suffers from high myopia of both eyes. She uses contact lenses on the right eye -20 D, on the left eye -16 D. During the ophthalmological consultation, the anterior chamber of the eye was moderately deep, the pupils and lenses were normal, the presence of an inclined disc of the II cranial nerve was demonstrated. Atrophy of the optic disc was detected, and retinal degenerative changes were present.

The thyroid ultrasound revealed several hypoechoic nodules in two lobes, not exceeding $3 \mathrm{~mm}$ in size, and the isthmus of the thyroid gland was dilated, but not exceeding $4 \mathrm{~mm}$.

\section{Treatment results, status at discharge, and recommendations:}

The patient was discharged after 115 days of stay at the Clinic. As a result of the treatment, the mental state and functioning improved partially. Auditory hallucinations and delusions subsided, affect revived, the psychomotor drive was normalized. The patient's statements became more fluid and fuller. The patient established contacts with other patients in the ward, willingly participated in school and therapeutic activities. The patient was on leave at home many times, where the mother and the patient observed the improvement of her mental state and functioning.

On the day of discharge, the patient was properly oriented auto- and allopsychically, in logical contact, calm, her behavior was adequate to the situation. She was not delusional and had no complaints of somatic nature. She denied the existence of suicidal thoughts and tendencies as well as auto-aggressive tendencies. On the MINI scale, she obtained 0 points, which is parallel to a low risk of suicide. She denied the presence of auditory hallucinations. Psychomotor drive and mood were balanced. At the moment of discharge, the patient's BMI increased compared to the day of admission and amounted to 22.43, which indicated a normal body weight.

The patient was discharged with the recommendation to systematically take drugs: clozapine, (tab. p. o.), after. $175 \mathrm{mg} /$ day, risperidone, (tab. p. o.), $0.75 \mathrm{mg} /$ day, aripiprazole (tab. p. o.), $30 \mathrm{mg} /$ day, sertraline (tab. p. o.) $100 \mathrm{mg} /$ day, vitamin B6 (tab. p. o.), $50 \mathrm{mg} /$ day. It was also recommended to continue the treatment under the conditions of the Mental Health Clinic (first visit in a month) and regular quarterly tests of fasting glucose, BMI, lipid panel, liver parameters, and thyroid gland. The patient was informed of the need for weekly blood counts in connection with taking clozapine. Moreover, in agreement with the Department of Gynecology, the term 
of the surgical treatment of ovarian cysts was set.

\section{Discussion:}

According to the current scientific literature, both pre- and perinatal adverse environmental factors significantly increase the risk of schizophrenia spectrum disorders. The presented case of a patient from a complicated double pregnancy ending in preterm labor, suffering from numerous perinatal complications, may indicate a neurodevelopmental basis of schizophrenia.

According to the "2-hits model" proposed by Keshavan in 1999, the greatest risk of developing schizophrenia occurs when a harmful factor acts in critical stages of the development of the central nervous system [10,24,25]. The first of these critical periods of neurodevelopment occurs in the 8-16th week of pregnancy, when neuroblasts migrate along the glial fibers to their destinations $[10,24,26]$. The second particularly important period of brain shaping is the stage of neuron pruning, which takes place during adolescence $[10,24,25,27]$.

In the presented clinical case, there are no indications that the harmful factor affected the fetus in the first or second trimester, i.e. during the migration of neuroblasts. The interview collected from the patient's mother negates any irregularities in this period. Moreover, the patient had no congenital abnormalities indicative of neurodevelopmental disorders that arose during this period, such as agenesis of the corpus callosum, stenosis of the aqueduct of Sylvius, or hamartoma [28]. There were also no abnormalities that indicated the factor's activity in the first trimester of pregnancy, such as diagonal eye folds, low-set ears, or wide spaces between the first and second fingers [28].

The medical interview shows that at the beginning of the third trimester there was a harmful factor. At this time, the stage of differentiation of brain structures and an intensive increase in the number of synaptic connections begins. There is evidence documented by research that a bacterial infection in the mother may be associated with an increased risk of schizophrenia spectrum disorders in the offspring [24]. Our patient's mother's pyelonephritis initiated a cascade of negative events which, according to the current scientific knowledge, could disrupt her normal neurodevelopment and contribute to her schizophrenia $[10,29]$. In the case of the patient described by us, these events included: preterm delivery in the 29th week of pregnancy and other complications related to prematurity, i.e. low birth weight (1010g), low Apgar Score, postpartum period complicated by numerous diseases. The epidemiological studies conducted clearly indicate that preterm labor ( $<37$ weeks, $<2055 \mathrm{~g}$ ) is a significant risk factor for many mental disorders, including schizophrenia [30].
The patient's disturbed neurodevelopment was evidenced by the fact that she began to walk at the age of 2 , and to speak at the age of 4 . In the 5 th year of life, the psychomotor development of the patient was still delayed by a year in relation to the peer group. This fact seems to be important in the light of the studies conducted so far, which reveal that delayed achievement of motor milestones (sitting, standing, and / or unsupported walking) is associated with a higher risk of schizophrenia $[10,31,32]$. In primary and secondary schools, the mental development of the patient was lower than average. There is strong scientific evidence that poor cognitive functioning in middle childhood (6-12 years of age) may be associated with the later onset of schizophrenia [29].

At the age of 9, the patient experienced a very stressful event - retinal detachment, for which she was treated surgically. Traumas and highly stressful events, as observed by many researchers who deal with the topic of neurodevelopmental etiology of schizophrenia, may disturb the process of neuronal pruning, which takes place actively in this period of life [33].

It is known that in the nervous system, complement plays an important role in synaptic pruning through phagocytosis of unnecessary synapses, as well as increased secretion of pro-inflammatory cytokines by glial cells, resulting in neuronal damage and death [27]. Environmental factors, including intrauterine infections, can lead to complement abnormalities and inflammation by activating the mother's immune system [27]. It is assumed that fetal exposure to maternal complement proteins may be a risk factor for the development of schizophrenia later in the child's life [27]. We have reason to believe that such exposure probably occurred in the case of our patient, at a time when her mother was diagnosed with pyelonephritis.

Moreover, the genetic factors responsible for the expression of complement (C4) may be one of the mechanisms underlying synaptic excessive pruning and thus lead to the development of the disease [26]. The patient described above suffered from postoperative adhesions of the abdominal cavity, physical exertion caused her severe pain and fever since early adolescence. Hence, it can be assumed that the patient could have had a second stroke at this time, due to excessive activation of the complement system.

Magnetic resonance imaging (MRI) performed on our patient did not reveal any abnormalities. This fact is in contrast to one of the evidence supporting the neurodevelopmental basis of schizophrenia, which are the results of research, which shows that morphological changes of the brain are more often observed among people suffering from it than in healthy people or people suffering from other mental problems [34]. However, on 
the basis of conventional magnetic resonance imaging, the presence of minor structural changes, that may be functionally significant, cannot be ruled out [35]. Moreover, taking into account the patient's medical history, it would be important to consider organic delusional disorders in the differential diagnosis. The patient experienced persecutory delusions that can occur both in paranoid schizophrenia and in organic delusional disorders [36]. However, the diagnosis of schizophrenia was supported by other symptoms reported by her, which are characteristic of this disease entity: commentary hallucinations, delusions of reference, and negative symptoms such as flattened affect, apathy, impoverished thinking, and speech [1,2].

The described patient, both in the perinatal period and later, was burdened with many health problems, both acute (retinopathy of prematurity, salmonella, intestinal obstruction, retinal detachment) and chronic (delay in the stages of physiological development, severe visual impairment, chronic increased abdominal pain caused by postoperative adhesions). At the age of 23 , she was hospitalized for the first time psychiatrically, with the final diagnosis of paranoid schizophrenia. The patient's fraternal twin sister, despite her prematurity, developed within the norms for gender, and age and was not burdened with any somatic or mental illnesses. The history of the patient's disease raises suspicions of the neurodevelopmental basis of her disease. It seems justified to pay special attention to the factors influencing the development of the CNS already in the fetal life, perinatal period, and early childhood, and to monitor children from risk groups in terms of their mental and physical health.

\section{Conclusions}

Despite the fact that the neurodevelopmental theory of schizophrenia was presented three decades ago and diagnostic methods have been dynamically developed, it is still impossible to determine the factors that would fully explain the pathogenesis of this disease. The effect of insufficient understanding of these mechanisms is, in a way, the therapeutic stagnation in the treatment of schizophrenia. The heterogeneous nature of symptoms is another factor that makes it difficult to establish a uniform pattern of correlation between genetic and environmental factors, which would lead to the development of the disease. The presented case of a patient with a complicated twin pregnancy suggests that particular attention should be paid to factors influencing the development of the CNS in utero, perinatal and early childhood. Probably in the future, in the still developing neurodevelopmental theory of schizophrenia, other factors will also be taken into account, as a result of which symptoms appeared in the described patient. Identifying the causes underlying the development of the disease is a key step towards prevention, more efficient diagnosis, and improvement of the effectiveness of treatment of patients suffering from this disease.

\section{Wstęp:}

Schizofrenia jest chorobą o złożonym charakterze i niejednorodnych objawach w aspektach behawioralnych i poznawczych [1]. Jej przebieg jest zmienny osobniczo i może przejawiać się pojedynczym epizodem, przez nawroty przerywane okresami bezobjawowymi aż po postać charakteryzującą się stałym występowaniem objawów [2]. Według raportu Global Burden of Disease z 2017 roku, dotyka ona ponad 20 milionów osób na świecie [3]. Szacuje się, że około 2/3 nowych diagnoz schizofrenii stawianych jest przed 45 rokiem życia [2]. Choroba ta odpowiada za pogorszenie jakości życia oraz zmniejszone uczestnictwo w środowisku zawodowym i społecznym [2]. W porównaniu do 2007 roku, wyliczony dekadę później wskaźnik lat przeżytych w niepełnosprawności (ang. Years Lived With Disability, YLD) uwzględniający schizofrenię wzrósł o około $17.2 \%$ [3]. Istotnym faktem dotyczącym osób cierpiących na tę chorobę jest również to, że oczekiwana długość ich może być krótsza nawet o 10 do 25 lat w porównaniu do populacji ogólnej [4,5].

$\mathrm{Na}$ chwilę obecną nie jest możliwe jednoznaczne wskazanie przyczyn stojących za rozwojem schizofrenii a szczegółowa patogeneza tej choroby jest przedmiotem wielu trwających badań. Proponowane koncepcje opierają się na współdziałaniu wielu czynników wśród których najważniejszą rolę wydają się mieć aspekty genetyczne, środowiskowe oraz nieprawidłowy rozwój ośrodkowego układu nerwowego (OUN) w różnych okresach jego kształtowania. Schizofrenia charakteryzuje się wysoką dziedzicznością, szacuje się, że ryzyko zachorowania jest nawet do 17 razy większe u krewnych pierwszego stopnia, a u bliźniąt monozygotycznych aż 40-50 razy większe w porównaniu z populacją ogólną [6]. Mimo licznych badań nad genomem człowieka udało się jedynie ustalić, że niektóre z genów mogą predysponować do rozwinięcia schizofrenii w przyszłości, jednak jedynie ich zmieniona ekspresja nie jest odpowiedzialna za pojawienie się objawów $[7,8,9]$.

Ekspozycja na czynniki środowiskowe korelujące z nieprawidłowym neurorozwojem może wystąpić zarówno w okresie prenatalnym, dzieciństwa jak i adolescencji. Wśród bodźców działających podczas życia płodowego, które mogą predysponować do wystąpienia 
anomalii wymienia się m.in., infekcję Toxoplasma gondii [10], niedożywienie [11], niedobór żelaza [12] oraz witaminy D [13] u ciężarnych. Analogiczny skutek mogą mieć powikłania okołoporodowe w postaci stanu przedrzucawkowego lub porodu przedwczesnego. [14] W czasie dzieciństwa oraz adolescencji istotnego znaczenia dla rozwoju układu nerwowego nabierają również przebyte traumy oraz niski status socjoekonomiczny [15].

Teoria neurorozwojowa schizofrenii opiera się na założeniu, że postać objawowa jest finalnym efektem niefizjologicznego rozwoju OUN, który został spowodowany współdziałaniem czynników genetycznych i środowiskowych jeszcze podczas jego kształtowania. Koncept nieprawidłowej budowy OUN jako przyczyny ujawnienia schizofrenii w przyszłości został po raz pierwszy zaproponowany około 30 lat temu przez I. Feinberg [16], T. Crow [17], D. Weinberger [18] oraz R. Murray i S. Lewis [19]. Od tego momentu teoria ta była uzupełniana o element tzw. „drugiego uderzenia”. J. Davis i wsp. w swojej pracy postulują, iż model ten może cechować się nadmiernym uproszczeniem patogenezy schizofrenii a szansę na lepsze odzwierciedlenie współdziałania czynników genetycznych, środowiskowych i społecznych ma hipoteza „wielu trafień” w kluczowych momentach rozwoju OUN [15].

Teoria o neurorozwojowym podłożu schizofrenii znajduje swoje odzwierciedlenie w badaniach obrazowych OUN. Za pomocą badania jedną z sekwencji rezonansu magnetycznego, obrazowania tensora dyfuzji (ang. diffusion tensor imaging, DTI), wykazano, że ilość istoty białej u osób ze schizofrenią jest zmniejszona aż w 15 regionach mózgu głównie prawego górnego płata skroniowego oraz ciała modzelowatego już w początkowym okresie choroby [20]. Ubytki dotyczą również istoty szarej w szczególności kory czołowej, wyspy oraz zakrętu skroniowego górnego [21]. Wśród zmian obecnych w OUN obserwuje się również zmniejszone zagęszczenie kolców dendrytycznych pokrywających synapsy [22] oraz obniżoną ilość białek synaptycznych [23].

Celem niniejszego artykułu jest przedstawienie przypadku klinicznego, w którym ekspozycja na liczne niekorzystne czynniki środowiskowe w okresie pre i postnatalnym mogło być przyczyną rozwoju schizofrenii w życiu dorosłym.

\section{Metoda:}

Analiza przypadku klinicznego i dokumentacji medycznej pacjentki $\mathrm{z}$ rozpoznaniem schizofrenii paranoidlanej, u której wystąpiły liczne powikłania okołoporodowe. Analizy przypadku dokonano w oparciu o dane bibliograficzne (liczba pozycji - 36), opublikowanych w latach 1982-2021, a uzyskanych z baz;
PubMed, Google Scholar

\section{Opis przypadku:}

Pacjentka w wieku 23 lat, panna, bezdzietna. Po uzyskaniu wykształcenia średniego wstąpiła do szkoły policealnej, do której obecnie uczęszcza. Rodzice pacjentki są rozwiedzeni, mieszka z matką, natomiast z ojcem utrzymuje sporadyczny kontakt. Chora ma siostrę bliźniaczkę dwujajową, zdrową. W wywiadzie neguje nadużywanie alkoholu oraz substancji psychoaktywnych. Wywiad rodzinny w kierunku zaburzeń psychicznych i chorób genetycznych jest dodatni ze strony dalszej rodziny ojca pacjentki, dokładna diagnoza nie jest znana.

Pacjentka z ciąży pierwszej bliźniaczej, poród pierwszy. Poród odbył się drogą cięcia cesarskiego w 29 tygodniu ciąży z powodu zapalenia odmiedniczkowego nerek u matki. Masa ciała w chwili urodzenia wynosiła 1010g (przy normie ok. 2800-3800 g). W skali Apgar uzyskała w 1 minucie 4 pkt., w 3 minucie 6 pkt., obie punktacje wskazują według skali na stan średni noworodka. W okresie okołoporodowym wystąpiły powikłania $\mathrm{w}$ postaci położenia miednicowego, martwiczego zapalenia jelit, niedrożności jelit, obustronnego zapalenia płuc. W okresie noworodkowym pacjentka przebyła retinopatię wcześniaczą, salmonellę, zakażenie wirusowe, żółtaczkę, niedokrwistość. W drugim miesiącu życia $\mathrm{z}$ powodu niedrożności jelit zastosowano leczenie operacyjne. Pacjentka od urodzenia była karmiona sztucznie mieszankami mlecznymi.

Kamienie milowe występowały o czasie z wyjątkiem mowy, która pojawiła się ok. 4 roku życia oraz umiejętności chodzenia, którą wykształciła w 2 roku życia. W wieku 5 lat rozwój psychoruchowy był zaburzony, a opóźnienie rozwoju oszacowano jako zmniejszone o rok w stosunku do grupy rówieśniczej. W 9 roku życia wystąpiło odwarstwienie siatkówki, z tego powodu była leczona operacyjnie. Ze względu na dużą wadę wzroku oraz rozwój umysłowy na poziomie niższym niż przeciętny, w szkole gimnazjalnej oraz podstawowej pacjentka była kształcona w szkole specjalnej dla osób niedowidzących. W szkole gimnazjalnej oraz średniej zwolniona była $\mathrm{z}$ zajęć wychowania fizycznego ze względu na nasilone bóle brzucha, gorączkę, występujące po aktywności fizycznej, spowodowane zrostami pooperacyjnymi jamy brzusznej.

\section{Stan przy przyjęciu oraz historia choroby:}

Pierwsze zaburzenia miały swój początek w kwietniu 2018r. pod postacią urojeń prześladowczych, ksobnych a także halucynacji słuchowych (głosów komentujących, grożących) oraz halucynacji węchowych. Z powodu znacznego nasilenia objawów wytwórczych w dniach 07.06.2018 - 12.06.2018 pacjentka była hospitalizowana w Szpitalu Neuropsychiatrycznym 
w Lublinie z rozpoznaniem: Ostre i przemijające zaburzenia psychotyczne, nieokreślone (F23.9). W dniu 12.06.2018 została przyjęta do Oddziału Psychiatrii dla Dzieci i Młodzieży tutejszej Kliniki Psychiatrii, Psychoterapii i Wczesnej Interwencji w Lublinie celem kontynuacji leczenia. W dniu przyjęcia pacjentka była prawidłowo zorientowana auto- i allopsychicznie. Wykazywała kontakt słowny logiczny a nastój i napęd były wyrównane. Treści urojeniowych spontanicznie nie wypowiadała, negowała występowanie omamów oraz myśli samobójczych. W skali MINI uzyskała 0 punktów co świadczyło o niskim ryzyku samobójczym.

W pierwszym dniu po przyjęciu pacjentki (tj. 13. 08. 2018) pobrano krew na czczo a wyniki badań laboratoryjnych wykazały następujące nieprawidłowości: glukoza- 99,4; (norma: 70- $99 \mathrm{mg} / \mathrm{dl}$ ), białko całkowite5,73; (norma: 6,40-8,30 g/dl), cholesterol całkowity108,6; (norma: 115-190 mg/dl), tyroksyna wolna FT420,32; (norma: 9,0-20,0 pmol/l), \% neutrocytów- 73,3; (norma: 45,0-70,0\%), \% limfocytów- 17,5; (norma: 20,0-45,0), \% eozynocytów- 0,20; (norma: 1,0-5,0). BMI pacjentki wynosiło 19,63 , co odpowiada prawidłowej masie ciała.

\section{Przebieg hospitalizacji i zastosowane leczenie:}

Początkowo pacjentka była blada afektywnie, w znacznie obniżonym napędzie psychoruchowym, aspontaniczna, bierna i apatyczna. Wypowiadała treści urojeniowe o charakterze prześladowczym oraz ksobnym. Zgłaszała obecność omamów złożonych (głosy komentujące) oraz proste (stuki, puki). Epizodycznie skarżyła się na obecność halucynacji węchowych (nieprzyjemne zapachy, zapach „zwłok”). Na zadawane pytania odpowiadała pojedynczymi słowami, wypowiedzi były bardzo zubożone, mówiła cichym głosem.

W dniu przyjęcia zastosowano jednorazowo perazynę tabl. p.o. w dawce $25 \mathrm{mg}$ i pridinol tabl. p.o. w dawce $5 \mathrm{mg}$ (dotychczasowe leczenie pacjentki) oraz kontynuowano leczenie olanzapiną tabl. p.o.. stopniowo zwiększając dawkę w ciągu następnych kilku dni do 20 $\mathrm{mg} /$ dobę. Ze względu na utrzymywanie się objawów wytwórczych, a także znaczne spowolnienie ruchowe i apatię u pacjentki w 22 dobie hospitalizacji do leczenia włączono arypiprazol tabl. p.o. dochodząc do dawki maksymalnej $30 \mathrm{mg}$. Pomimo wdrążonej farmakoterapii stan pacjentki nie uległ satysfakcjonującej poprawie. W 51 dobie hospitalizacji włączono do leczenia risperidon tabl .p.o. (zastosowana dawka maksymalne $3 \mathrm{mg}$ ) oraz w 58 dobie sertralinę (dawka maksymalna $100 \mathrm{mg}$ ). Pacjentka poddana była kwalifikacji do zabiegów elektrycznych, jednak ze względu na torbiel jajnika lewego konieczne było odstąpienie od tej formy terapii. Zdecydowano o stopniowym ostawieniu olanzapiny i po wykluczeniu przeciwskazań włączono klozapinę, stopniowo zwiększano dawkę do $175 \mathrm{mg}$. Podczas hospitalizacji pacjentka korzystała z psychoterapii wspierającej, psychoedukacji, terapii zajęciowej, muzycznej, arteterapii i treningu kulinarnego.

W trakcie pobytu wykonano szereg badań laboratoryjnych oraz obrazowych, a także konsultacji neurologicznych, internistycznych, ginekologicznych i okulistycznych. Tydzień po przyjęciu, w trakcie stosowania olanzapiny, pacjentka miała wykonane badanie elektroencefalograficzne, w którym zostały uwidocznione nieprawidłowości. Widoczne były zmiany uogólnione, z niestałą, obustronną, wyraźniej zaznaczoną po stronie prawej, przewagą w okolicach czołowo-skroniowych, w postaci fal theta, sporadycznie wyżejnapięciowych wyładowań nieregularnych fal thetadelta i ostrych. Czynność podstawowa była nieregularna, z rozsianymi nad przednim obszarem mózgu falami wolnymi theta.

Pacjentka była konsultowana neurologicznie ze względu na nieprawidłowy wynik badania EEG oraz skargi na odczuwanie nieprzyjemnych zapachów (zapachu „zwłok”). Konsultujący neurolog celem wykluczenia podejrzenia zaburzeń skroniowych zalecił badanie MRI głowy, które wykonano 2 lipca 2018 roku. Wynik badania był prawidłowy, bez odchyleń od normy.

Pacjentka ze względu na zgłaszane bóle brzucha była konsultowana ginekologicznie, w badaniu USG uwidoczniono torbiel jajnika lewego o charakterze endometrialnym oraz skierowano pacjentkę na leczenie operacyjne.

W badaniu przeprowadzonym z użyciem Skali Inteligencji WAIS-R PL określono ogólną sprawność umysłową na pograniczu normy i upośledzenia, w Skali Pełnej II=78. Nie było istotnie statystycznej różnicy między zdolnościami werbalnymi, (w Skali Słownej II=80) a zdolnościami niewerbalnymi (w Skali Bezsłownej II= 77). Podczas wykonywania zadań pacjentka wykazywała zaangażowanie. Umiejętności, które u pacjentki wypadły korzystnie to: pamięć krótkotrwała słuchowa, bezpośrednie przypominanie, przewidywanie relacji między elementami i ich integracja. Poniżej przeciętnej były umiejętności interpretowania i organizacji materiału za pomocą wzroku oraz odporność na dystraktory.

Kolejne badanie elektroencefalograficzne podczas terapii risperidonem, arypiprazolem, sertraliną wykonano 14 sierpnia 2018 roku. Widoczna była poprawa zapisu w stosunku do poprzedniego badania, ale również występowały nieprawidłowościami. Zmiany uogólnione, także bardziej widoczne w okolicy czołowo - skroniowej prawej, były słabo uwydatnione, aktywowane hiperwentylacją, pojedyncze wyżejnapięciowego wyładowania fal delta-theta. 
Pacjentka choruje na krótkowzroczność wysoką oka prawego i lewego. Korzysta z soczewek kontaktowych na oku prawym -20 D, na oku lewym -16 D. Podczas konsultacji okulistycznej komora przednia oka była miernie głęboka, źrenice i soczewki prawidłowe, wykazano obecność pochyłej tarczy nerwu II. Wykryto zanik okołotarczowy, obecne były zmiany zwyrodnieniowe siatkówki.

W wykonanym USG tarczycy uwidoczniono kilka hipoechogenicznych guzków, w dwóch płatach, o wielkości nieprzekraczającej $3 \mathrm{~mm}$, a cieśń tarczycy była poszerzona, nieprzekraczająca jednak $4 \mathrm{~mm}$.

\section{Rezultaty zastosowanego leczenia, stan przy wypisie i zalecenia:}

Pacjentka została wypisana po 115 dniach pobytu w Klinice. W wyniku wdrożonego leczenia nastąpiła częściowa poprawa stanu psychicznego i funkcjonowania. Halucynacje słuchowe oraz urojenia ustąpiły, afekt się ożywił, napęd psychoruchowy uległ normalizacji. Wypowiedzi pacjentki stały się bardziej płynne oraz pełniejsze. Pacjentka nawiązała kontakty $\mathrm{z}$ innymi pacjentami w oddziale, chętnie uczestniczyła w zajęciach szkolnych i terapeutycznych. Pacjentka wielokrotnie przebywała na przepustkach w domu, gdzie matka i pacjentka obserwowały poprawę stanu psychicznego i funkcjonowania.

W dniu wypisu pacjentka była prawidłowo zorientowana auto- i allopsychicznie, w logicznym kontakcie, spokojna, jej zachowanie było adekwatne do sytuacji. Nie wykazywała urojeń, i nie zgłaszała skarg na dolegliwości somatyczne. Zaprzeczała występowaniu myśli i tendencji suicydialnych oraz tendencji autoagresywnych. W skali MINI uzyskała 0 pkt. co odpowiada niskiemu ryzyku samobójczemu. Negowała obecność omamów słuchowych. Napęd psychoruchowy oraz nastrój były wyrównane wyrównane. W momencie wypisu BMI pacjentki wzrosło w porównaniu do dnia przyjęcia i wynosiło 22,43 , co świadczyło o prawidłowej masie ciała.

Pacjentka została wypisana $\mathrm{z}$ zaleceniem systematycznego przyjmowania leków: klozapiny tabl. p.o. 175/dobę., risperidonu tabl. p.o. 0,75 mg/dobę, arypiprazolu tabl. p.o. $30 \mathrm{mg} / \mathrm{d}$, sertraliny $100 \mathrm{mg}$ tabl. p.o./dobę, witamina B6 tabl.p.o. $50 \mathrm{mg} /$ dobę. Zalecono również kontynuację leczenia w warunkach Poradni Zdrowia Psychicznego (pierwsza wizyta za miesiąc) oraz regularne raz na kwartał badania glikemii na czczo, BMI, panelu lipidowego, parametrów wątrobowych i tarczycy. Poinformowano pacjentkę o konieczności cotygodniowego badania morfologii krwi w związku z przyjmowaniem klozapiny. Ponadto w porozumieniu z Kliniką Ginekologii został wyznaczony termin operacyjnego leczenia torbieli jajnika.
Dyskusja:

Zgodnie z aktualną literaturą naukową zarówno przed- jak i okołoporodowe niekorzystne czynniki środowiskowe znacznie zwiększają ryzyko zaburzeń ze spektrum schizofrenii. Przedstawiony przez nas przypadek pacjentki z powikłanej ciąży bliźniaczej dwujajowej, zakończonej porodem przedwczesnym, dotkniętej licznymi powikłaniami okołoporodowymi może wskazywać na neurorozwojowe podłoże schizofrenii.

Zgodnie z modelem podwójnego uderzenia („2-hits model") zaproponowanym przez Keshavana w 1999 roku największe ryzyko zachorowania na schizofrenie występuje gdy szkodliwy czynnik zadziała w krytycznych etapach rozwoju ośrodkowego układu nerwowego $[10,24,25]$. Pierwszy $\mathrm{z}$ tych krytycznych okresów neurorozwoju przypada na 8-16 tydzień ciąży, w tym czasie dochodzi do migracji neuroblastów wzdłuż włókien glejowych do ich miejsc przeznaczenia $[10,24,26]$. Drugi szczególnie ważny okres kształtowania mózgowia to etap przycinania neuronów („pruningu”), który odbywa się w okresie adolescencji $[10,24,25,27]$.

W prezentowanym przez nas przypadku klinicznym brak jest przesłanek co do tego, że szkodliwy czynnik zadziałał na płód w I lub II trymestrze, czyli w trakcie migracji neuroblastów. Wywiad zebrany od matki pacjentki neguje jakiekolwiek nieprawidłowości w tym okresie. Ponadto $\mathrm{u}$ pacjentki nie stwierdzono wad wrodzonych wskazujących na zaburzenia neurorozwojowe powstałe w tym właśnie okresie, takich jak agenezja ciała modzelowatego, zwężenie wodociągu Sylwiusza, hamartoma [28]. Nieobecne były również anomalie wskazujące na zadziałanie czynnika w pierwszym trymestrze ciąży takich jak fałdy nakątne oczu, nisko osadzone uszy lub szerokie przestrzenie między pierwszymi i drugimi palcami [28].

Z wywiadu lekarskiego wynika, że na początku III trymestru doszło do zadziałania szkodliwego czynnika. W tym czasie zaczyna się etap różnicowania struktur mózgu oraz intensywnego wzrostu liczby połączeń synaptycznych. Istnieją udokumentowane badaniami przesłanki, wskazujące że infekcja bakteryjna u matki może być związana ze zwiększonym ryzykiem wystąpienia zaburzeń ze spektrum schizofrenii u potomstwa [24]. Odmiedniczkowe zapalenie nerek u matki naszej pacjentki zapoczątkowało kaskadę negatywnych wydarzeń, które zgodnie z aktualną wiedzą naukową mogły zakłócić jej prawidłowy neurorozwój i przyczynić się do jej zachorowania na schizofrenie $[10,29]$. Do zdarzeń tych w przypadku opisanej przez nas chorej należały: poród przedwczesny w 29 tygodniu ciąży, i inne powikłania związane ze wcześniactwem tj. niska masa urodzeniowa (1010g), niski wynik w skali Apgar, 
okres poporodowy powikłany licznymi schorzeniami. Prowadzone badania epidemiologiczne wskazują wyraźnie, że poród przedwczesny (<37 tygodni, <2055 g) jest istotnym czynnikiem ryzyka wielu zaburzeń psychicznych, w tym również schizofrenii [30].

0 zaburzonym neurorozwoju pacjentki świadczyło to, że zaczęła chodzić w 2 roku życia, natomiast mówić dopiero w 4 roku życia. W 5 roku życia rozwój psychoruchowy pacjentki nadal był opóźniony o rok w stosunku do grupy rówieśniczej. Fakt ten wydaje się być istotny $\mathrm{w}$ świetle dotychczasowych badań, które ujawniają, że opóźnione osiąganie kamieni milowych motorycznych (siadania, stania i/lub chodzenia bez podparcia) związane jest z wyższym ryzykiem schizofrenii [10,31,32]. W szkole podstawowej i gimnazjalnej rozwój umysłowy chorej był na poziomie niższym niż przeciętny. Istnieją mocne dowody naukowe wskazujące, że słabe funkcjonowanie poznawcze w średnim dzieciństwie (6-12 lat) może być związane z późniejszym zachorowaniem na schizofrenie [29].

Pacjentka w 9 roku życia doświadczyła bardzo stresującego wydarzenia - odwarstwienie siatkówki, z którego powodu była leczona operacyjnie. Traumy i silnie stresujące zdarzenia zgodnie $\mathrm{z}$ obserwacjami wielu badaczy, podejmujących tematykę neurorozwojowej etiologii schizofrenii mogą zaburzać proces przycinania neuronów, który zachodzi aktywnie w tym okresie życia [33].

Wiadomym jest, iż w układzie nerwowym układ dopełniacza odgrywają istotną rolę $\mathrm{w}$ przycinaniu synaptycznym, poprzez fagocytozę zbędnych synaps, a także zwiększone wydzielanie cytokin prozapalnych przez komórki glejowe, powodujące uszkodzenie neuronów i ich śmierć [27]. Czynniki środowiskowe, w tym infekcje wewnątrzmaciczne, mogą prowadzić do nieprawidłowości w układzie dopełniacza i zmian zapalnych poprzez aktywację układu odpornościowego matki [27]. Przypuszcza się, że ekspozycja płodu na matczyne białka dopełniacza może być czynnikiem ryzyka rozwoju schizofrenii u dziecka [27]. Mamy podstawy aby przypuszczać, że taka ekspozycja prawdopodobnie miała miejsce w przypadku naszej pacjentki, w czasie gdy jej matka zachorowała na odmiedniczkowe zapalenie nerek.

Ponadto, czynniki genetyczne odpowiedzialne za ekspresję dopełniacza (C4) mogą być jednym z mechanizmów leżących u podstaw nadmiernego przycinania synaptycznego („prunningu”) a tym samym prowadzić do rozwoju choroby [26]. Opisana przez nas pacjentka od okresu wczesnonastoletniego cierpiała $\mathrm{z}$ powodu zrostów pooperacyjnych jamy brzusznej, wysiłek fizyczny, powodował u niej silny ból oraz gorączkę. Skąd można przypuszczać, że mogło dojść w tym czasie u pacjentki do drugiego uderzenia, poprzez nadmierną aktywację układu dopełniacza.

Badanie rezonansu magnetycznego (MR) wykonane u naszej pacjentki, nie ujawniało żadnych odchyleń od normy. Fakt ten jest w opozycji do jednego z dowodów przemawiających za neurorozwojowym podłożem schizofrenii, którym są wyniki badań, ujawniające, że wśród osób na nią chorujących częściej obserwuje się zmiany morfologiczne mózgu niż u osób zdrowych lub dotkniętych innymi problemami psychicznymi [34]. Jednak, na podstawie konwencjonalnego badania $\mathrm{z}$ użyciem rezonansu magnetycznego nie można wykluczyć obecności drobnych zmian strukturalnych mogących mieć znaczenie czynnościowe [35]. Ponadto zważając na historię choroby pacjentki w diagnostyce różnicowej istotnym byłoby wziąć pod uwagę organiczne zaburzenia urojeniowe. Chora doświadczała urojeń prześladowczych, które mogą wystąpić zarówno we schizofrenii paranoidalnej jak i w organicznych zaburzeniach urojeniowych [36]. Jednakże, za rozpoznaniem u pacjentki schizofrenii przemawiały inne zgłaszane przez nią objawy, które są charakterystyczne dla tej jednostki chorobowej: omamy słuchowe komentujące i ksobne oraz objawy negatywne takie jak spłycony afekt, apatia, zubożenie myślenia i wypowiedzi [1,2].

Opisana przez nas pacjentka zarówno w okresie okołoporodowym jak i od urodzenia obciążona była wieloma problemami zdrowotnymi, zarówno o przebiegu ostrym ( retinopatia wcześniacza, salmonella, niedrożność jelit, odwarstwienie siatkówki) jak i przewlekłym (opóźnienie etapów rozwoju fizjologicznego, duża wada wzroku, przewlekłe nasilone bóle jamy brzusznej spowodowane zrostami pooperacyjnymi). W wieku 23 lat po raz pierwszy była hospitalizowana psychiatrycznie, z ostatecznie postawionym rozpoznaniem schizofrenii paranoidalnej. Siostra bliźniczka dwujajowa pacjentki, pomimo wcześniactwa, rozwijała się $w$ granicach normy dla płci i wieku, nie była obciążona chorobami somatycznymi i psychicznymi. Historia choroby przedstawionej przez nas pacjentki nasuwa podejrzenie na neurorozwojowe podłoże jej choroby. Zasadnym wydaje się zwrócić szczególną uwagę na czynniki mające wpływ na rozwój OUN już w życiu płodowym, okresie okołoporodowym i wczesnym dzieciństwie a dzieci z grup ryzyka monitorować pod kontem zdrowia psychicznego i fizycznego.

\section{Wnioski:}

Mimo, że teoria neurorozwojowa schizofrenii została zaproponowana już trzy dekady temu a metody diagnostyczne uległy dynamicznemu rozwojowi, nadal niemożliwe jest określenie czynników, które wyjaśniałyby całkowicie patogenezę tej choroby. Efektem niewystarczającego poznania tych mechanizmów jest 
poniekąd stagnacja terapeutyczna dotycząca leczenia schizofrenii. Czynnikiem, który dodatkowo utrudnia ustalenie jednolitego wzorca korelacji czynników genetycznych i środowiskowych, który miałby prowadzić do rozwoju choroby jest również heterogeniczny charakter objawów. Przedstawiony powyżej przypadek pacjentki z powikłanej ciąży bliźniaczej dwujajowej sugeruje, że należy zwrócić szczególną uwagę na czynniki mające wpływ na rozwój OUN już w życiu płodowym oraz okresie okołoporodowym i wczesnego dzieciństwa. Prawdopodobnie w przyszłości, we wciąż rozwijającej się teorii neurorozwojowej schizofrenii zostaną uwzględnione również inne czynniki, w wyniku których u opisanej pacjentki pojawiły się objawy. Identyfikacja przyczyn leżących u podłoża rozwoju choroby jest kluczowym krokiem w kierunku prewencji, sprawniejszej diagnostyki oraz poprawienia skuteczności leczenia pacjentów cierpiących na tę chorobę.

\section{Conflict of interest}

The authors have declared no conflict of interest.

\section{References:}

1. Owen MJ, Sawa A, Mortensen PB. Schizophrenia. Lancet 2016;388:86-97. https://doi.org/10.1016/S01406736(15)01121-6.

2. Hasan A, Falkai P, Lehmann I, Gaebel W. Schizophrenie. Dtsch Arztebl Int 2020;117:412-9. https://doi.org/10.3238/ arztebl.2020.0412.

3. James SL, Abate D, Abate KH, Abay SM, Abbafati C, Abbasi N, et al. Global, regional, and national incidence, prevalence, and years lived with disability for 354 Diseases and Injuries for 195 countries and territories, 1990-2017: A systematic analysis for the Global Burden of Disease Study 2017. Lancet 2018;392:1789858. https://doi.org/10.1016/S0140-6736(18)32279-7.

4. Simon GE, Stewart C, Yarborough BJ, Lynch F, Coleman KJ, Beck A, et al. Mortality rates after the first diagnosis of psychotic disorder in adolescents and young adults. JAMA Psychiatry 2018;75:254-60. https://doi.org/10.1001/ jamapsychiatry.2017.4437.

5. Plana-Ripoll O, Pedersen CB, Agerbo E, Holtz Y, Erlangsen A, Canudas-Romo V, et al. A comprehensive analysis of mortalityrelated health metrics associated with mental disorders: a nationwide, register-based cohort study. Lancet 2019;394:182735. https://doi.org/10.1016/S0140-6736(19)32316-5.

6. Cardno AG, Marshall EJ, Coid B, Macdonald AM, Ribchester TR, Davies NJ, et al. Heritability estimates for psychotic disorders: The Maudsley Twin psychosis series. Arch Gen Psychiatry 1999;56:162-8. https://doi.org/10.1001/archpsyc.56.2.162.

7. Ripke S, Neale BM, Corvin A, Walters JTR, Farh KH, Holmans PA, et al. Biological insights from 108 schizophrenia-associated genetic loci. Nature 2014;511:421-7. https://doi.org/10.1038/ nature13595.

8. Sullivan PF, Daly MJ, O’Donovan M. Genetic architectures of psychiatric disorders: The emerging picture and its implications. Nat Rev Genet 2012;13:537-51. https://doi. org/10.1038/nrg3240.

9. Balu DT. The NMDA Receptor and Schizophrenia. From Pathophysiology to Treatment. Adv. Pharmacol., vol. 76,
Academic Press Inc.; 2016, p. 351-82. https://doi.org/10.1016/ bs.apha.2016.01.006.

10. Rapoport JL, Giedd JN, Gogtay N. Neurodevelopmental model of schizophrenia: Update 2012. Mol Psychiatry 2012;17:1228-38. https://doi.org/10.1038/mp.2012.23.

11. McGrath J, Brown A, St Clair D. Prevention and schizophrenia - The role of dietary factors. Schizophr Bull 2011;37:272-83. https://doi.org/10.1093/schbul/sbq121.

12. Maxwell AM, Rao RB. Perinatal iron deficiency as an early risk factor for schizophrenia. Nutr Neurosci 2021:1-10. https://doi. org/10.1080/1028415X.2021.1943996.

13. Berridge MJ. Vitamin d deficiency: Infertility and neurodevelopmental diseases (attention deficit hyperactivity disorder, autism, and schizophrenia). Am J Physiol - Cell Physiol 2018;314:C135-51. https://doi.org/10.1152/ajpcell.00188.2017.

14. McCutcheon RA, Reis Marques T, Howes OD. Schizophrenia An Overview. JAMA Psychiatry 2020;77:201-10. https://doi. org/10.1001/jamapsychiatry.2019.3360.

15. Davis J, Eyre H, Jacka FN, Dodd S, Dean O, McEwen S, et al. A review of vulnerability and risks for schizophrenia: Beyond the two hit hypothesis. Neurosci Biobehav Rev 2016;65:185-94. https://doi.org/10.1016/j.neubiorev.2016.03.017.

16. Feinberg I. Schizophrenia: Caused by a fault in programmed synaptic elimination during adolescence? J Psychiatr Res 1982;17:319-34. https://doi.org/10.1016/00223956(82)90038-3.

17. Crow TJ. The two-syndrome concept: Origins and current status. Schizophr Bull 1985;11:471-86. https://doi.org/10.1093/ schbul/11.3.471.

18. Weinberger DR. Implications of Normal Brain Development for the Pathogenesis of Schizophrenia. Arch Gen Psychiatry 1987;44:660-9. https://doi.org/10.1001/ archpsyc.1987.01800190080012.

19. Murray RM, Lewis SW, Lecturer L. Is schizophrenia a neurodevelopmental disorder? Br Med J (Clin Res Ed) 1987;295:681-2. https://doi.org/10.1136/bmj.295.6600.681.

20. Koshiyama D, Fukunaga M, Okada N, Morita K, Nemoto K, Usui $\mathrm{K}$, et al. White matter microstructural alterations across four major psychiatric disorders: mega-analysis study in 2937 individuals. Mol Psychiatry 2020;25:883-95. https://doi. org/10.1038/s41380-019-0553-7.

21. Wójciak P, Remlinger-Molenda A, Rybakowski J, Psychiatrii K, Um W Poznaniu D. Etapy przebiegu schizofrenii-koncepcja stagingu Stages of the clinical course of schizophreniastaging concept. Psychiatr Pol 2016;50:717-30. https://doi. org/10.12740/PP/58723.

22. Radhakrishnan R, Skosnik PD, Ranganathan M, Naganawa M, Toyonaga T, Finnema $S$, et al. In vivo evidence of lower synaptic vesicle density in schizophrenia. Mol Psychiatry 2021:1-9. https://doi.org/10.1038/s41380-021-01184-0.

23. Osimo EF, Beck K, Reis Marques T, Howes OD. Synaptic loss in schizophrenia: a meta-analysis and systematic review of synaptic protein and mRNA measures. Mol Psychiatry 2019;24:549-61. https://doi.org/10.1038/s41380-018-0041-5.

24. Karakuła H, Pelczarska-Jamroga A, Dzikowski M, Próchnicki M, Dzikowska I. Czy schizofrenia rozpoczyna się w życiu płodowym? Dowody wspierające teorię neurorozwojową. Zdr i Dobrostan Dobrostan i Społeczeństwo 2013;4:111-20.

25. Frese FJ. Neurodevelopment and Schizophreniaedited by Matcheri Keshavan, James Kennedy, and Robin Murray; Cambridge, United Kingdom, Cambridge University Press, 2004, 520 pages, \$140. Psychiatr Serv 2006;57. https://doi. org/10.1176/ps.2006.57.6.887.

26. Morimoto K, Nakajima K. Role of the Immune System in the 
Development of the Central Nervous System. Front Neurosci 2019;13. https://doi.org/10.3389/fnins.2019.00916.

27. Keshavan M, Lizano $P$, Prasad K. The synaptic pruning hypothesis of schizophrenia: promises and challenges. World Psychiatry 2020;19. https://doi.org/10.1002/wps.20725.

28. Fatemi SH, Folsom TD. The neurodevelopmental hypothesis of Schizophrenia, revisited. Schizophr Bull 2009;35. https://doi. org/10.1093/schbul/sbn187.

29. Laurens KR, Luo L, Matheson SL, Carr VJ, Raudino A, Harris F, et al. Common or distinct pathways to psychosis? A systematic review of evidence from prospective studies for developmental risk factors and antecedents of the schizophrenia spectrum disorders and affective psychoses. BMC Psychiatry 2015;15. https://doi.org/10.1186/s12888-015-0562-2.

30. Johnson S, Marlow N. Preterm birth and childhood psychiatric disorders. Pediatr Res 2011;69. https://doi.org/10.1203/ PDR.0b013e318212faa0.

31. Clarke MC, Tanskanen A, Huttunen M, Leon DA, Murray RM, Jones PB, et al. Increased risk of schizophrenia from additive interaction between infant motor developmental delay and obstetric complications: Evidence from a population-based longitudinal study. Am J Psychiatry 2011;168. https://doi. org/10.1176/appi.ajp.2011.11010011.

32. Isohanni M, Jones PB, Moilanen K, Rantakallio P, Veijola J, Oja H, et al. Early developmental milestones in adult schizophrenia and other psychoses. A 31-year follow-up of the Northern Finland 1966 Birth Cohort. Schizophr. Res., vol. 52, 2001. https://doi. org/10.1016/S0920-9964(00)00179-1.

33. Germann M, Brederoo SG, Sommer IEC. Abnormal synaptic pruning during adolescence underlying the development of psychotic disorders. Curr Opin Psychiatry 2021;34. https://doi.
org/10.1097/YCO.0000000000000696.

34. Suddath RL, Christison GW, Torrey EF, Casanova MF, Weinberger DR. Anatomical Abnormalities in the Brains of Monozygotic Twins Discordant for Schizophrenia. N Engl J Med 1990;322. https://doi.org/10.1056/nejm199003223221201.

35. Zaborowski A, Antosik-Biernacka A, Biernacki R, Kłoszewska I, Stefańczyk L. Estimation of brain tissue in schizophrenic patients using magnetization transfer imaging - Preliminary report. Psychiatr Pol 2007;41.

36. Endres D, Matysik M, Feige B, Venhoff N, Schweizer T, Michel M, et al. Diagnosing organic causes of schizophrenia spectrum disorders: Findings from a one-year cohort of the Freiburg diagnostic protocol in psychosis (FDPP). Diagnostics 2020;10. https://doi.org/10.3390/diagnostics10090691.

\section{Corresponding author}

Paulina Wróbel-Knybel

I Department of Psychiatry, Psychotherapy and Early Intervention, Medical University of Lublin

Głuska 1 Street, 20-439 Lublin, Poland

e-mail: wrobelknybel.paulina@gmail.com

Otrzymano: 30.07.2021

Zrecenzowano: 02.08.2021

Przyjęto do druku: 06.09.2021 